\title{
Evaluation of protection against bovine viral diarrhea virus type 2 after vaccination of the calves with bovine viral diarrhea virus type 1 combo inactivated vaccine
}

\author{
[Avaliação da proteção contra o vírus da diarreia viral bovina tipo 2 após vacinação de \\ bezerros com vacina combinada inativada do vírus da diarreia viral bovina tipo 1] \\ C. Chen ${ }^{\#}$, Y. Liü, H. Huang, Q. Meng, M. Xia*, H. Wu* \\ Sinovet (Jiangsu) Biopharm. Co., Ltd., No.409 Jianggao Road, \\ Taizhou, Jiangsu province, China
}

\begin{abstract}
This study was designed to evaluate the extent of the protection for bovine viral diarrhea virus type 2 (BVDV-2) infection, afforded by vaccination with a combo inactivated vaccine, which contains bovine viral diarrhea virus type 1 (BVDV-1) and infectious bovine rhinotracheitis virus (IBRV). Five 3-4month-old calves were intramuscularly vaccinated with a single dose of the combo vaccine and boosted with same dose three weeks after the first vaccination, with five mock immunized calves serving as a control group. Twenty-one days after the second vaccination, all calves were challenged with BVDV-2 SX08 strain by spray into nostril. The unvaccinated animals developed typical clinical signs of high rectal temperature, diarrhoea with erosions and a dramatic drop in leukocyte counts. These signs occured markedly less in all vaccinated animals, the rectal temperature, leukopenia and virarmia of which, were significantly less than the mock immunized calves. It can be concluded that vaccination with the combo inactivated vaccine affords cross-protection against clinical effects of a challenge-infection with BVDV-2 SX08 strain, although it was part protection.
\end{abstract}

Keywords: vaccine, BVDV-1, BVDV-2, cross protection

\section{RESUMO}

Este estudo foi desenvolvido para avaliar a extensão da proteção contra a infecção pelo vírus da diarréia viral bovina tipo 2 (BVDV-2) através da vacinação com uma vacina combinada inativada contendo o vírus da diarréia viral bovina tipo 1 ( $B V D V-1)$ e vírus da rinotraqueíte de bovinos infecciosos (IBRV). Cinco bezerros com 3 a 4 meses de idade foram vacinados via intramuscular com uma dose única da vacina combinada e reforçados com a mesma dose três semanas após a primeira vacinação, com cinco bezerros imunizados em simulação servindo como grupo controle. Vinte e um dias após a segunda vacinação, todos os bezerros foram desafiados com a cepa BVDV-2 SX08 por spray na narina. Os animais não vacinados desenvolveram sinais clínicos típicos, como alta temperatura retal, diarréia com erosões e queda drástica na contagem de leucócitos. Estes sinais tiveram ocorrência significativamente menor em todos os animais vacinados, cuja temperatura retal, leucopenia e virarmia eram significativamente menores do que os bezerros simulados. É possível concluir que a vacinação com a vacina combinada inativada proporciona proteção cruzada contra os efeitos clínicos de uma infecção provocada pela cepa BVDV-2 SX08, embora tenha sido parcialmente protegida.

Palavras-chave: vacina, BVDV-1, BVDV-2, proteção cruzada

\section{INTRODUCTION}

Bovine virus diarrhoea virus (BVDV) is a major viral pathogen in cattle and causes considerable economic losses throughout the world. Its

Recebido em 24 de abril de 2019

Aceito em 24 de abril de 2019

*Autor para correspondência (corresponding author)

E-mail: xiamingqi@sinovetah.com; wuhua@sinovetah.com

"Equal contributors stealthy nature, prolonged transient infections, and the presence of persistently infected (PI) animals, which may appear healthy, as efficient reservoirs were responsible for its ubiquitous presence in cattle populations worldwide (Baker,1995; Moenniq and Becher, 2018). 
BVDV has been segregated into two genotypes, named type 1 and type 2 , by phylogenetic analysis based on comparison of sequences from the 5'-untranslated region of the genome (Ridpath et al., 1994).

Each genotype can be divided into more genetic subgroups, about fifteen genetic subgroups of BVDV type 1 (BVDV-1) and four genetic subgroups of BVDV type 2 (BVDV-2) (Xue et $a l ., 2010)$. In the field, BVDV-1 infections are more prevalent than the BVDV-2, but the virulence of BVDV-2 is higher than BVDV-1 (Makoschey et al., 2001). Now, the main measures for the prevention and control of the BVDV are vaccination of cattle herd and elimination of PI animals, but the majority of commercial BVDV vaccines contain only BVDV-1. The study of Fairbank and colleagues has demonstrated satisfactory cross protection of a modified live BVDV-1 Singer strain vaccine against BVDV-2 890 strain challenge (Fairbanks et al., 2003).

The efficacy of inactivated BVDV-1 vaccines against the BVDV-2 challenge has been demonstrated by Hamer (Hamers et al., 2003). This study indicated that the different kinds of clinical signs and viremia have significantly decreased in vaccinated animals, which were challenged with a virulent BVDV-2 890 strain. Although attenuated and inactivated BVDV-1 vaccines demonstrated effective cross-protection against BVDV-2 infection, the broad antigenic diversity of different strain of BVDV-1 and BVDV-2 places high demands on these vaccines, the extent of cross-protection afforded by a new developed vaccine has to be determined experimentally (Shimazaki et al., 2003; Xue et al., 2009; Xue et al., 2011). Therefore, it must be evaluated by animal experiments wheather the combo inactivated vaccine for BVDV -1 and bovine rhinotracheitis virus (IBRV), can afford cross-protection against the BVDV-2 SX08 strain infection.

\section{MATERIALS AND METHODS}

The challenge virus, BVDV-2 SX08 strain, was isolated originally from the leukocyte of a naturally infected calf in Shan $\mathrm{Xi}$ province, China, where infected cattle showed severe disease characterized by pyrexia, leukopenia, diarrhea and asthma. Virus isolation and serum neutralization tests were performed on Madin Darby bovine kindey (MDBK) cells. MDBK cells grown in Dulbecco Minimal Essen-tial Medium (DMEM), supplemented with 5\% newborn bovine serum. This cell line was maintained free of bacteria, mould, mycoplasma and of bovine viral diarrhea virus (BVDV).

Ten 3-4-month-old healthy Holstein calves (10 male) serologically negative (SN titer <1:2) for BVDV-1 and BVDV-2, as determined by virus neutralization. The animals' blood was BVDV-1negative and BVDV-2-negative by RT-PCR. The calves came from a commercial dairy farm without BVDV-1 and BVDV-2 related problems and were maintained on antibiotic-free feed, supplemented with hayand water ad libitum. All animal experiments were approved by the ethics committee of Sinovet (Jiangsu) Biopharm. Co., Ltd.

Cattle for the trials were kept at Sinovet (Jiangsu) Biopharm. Co., Ltd., inspection Animal Room, in controlled outdoor facilities of sufficient size that the space per animal complied with applicable animal welfare standards. There was no direct contact between the control group and the vaccinated group. Authorized personnel worked with the animals, supplying water ad libitum and feeding a complete ration once daily. Appropriately trained personnel observed all study animals daily, both pre- and postchallenge, and considered all cattle acceptably healthy for virus challenge.

BVDV-1 NM01 strain and IBRV LN01 strain, used as the vaccine strain, were inactivated with binary ethyleneimine (BEI; Sigma, USA), mixed with Montanide $^{\mathrm{TM}}$ ISA 206 VG (Seppic, France) adjuvant and then emulsified. Antigen of BVDV1 NM01 strain in the vaccine was batched at a minimum immunization level of $10^{7.0}$ TCID50/dose.

The animals were randomly divided in two groups. The first group $(n=5)$ consisted of five calves that were intramuscularly immunized with a single $2 \mathrm{ml}$ dose of the combo inactivated vaccine. The second group $(n=5)$ consisted of five calves that were mock immunized with $2 \mathrm{ml}$ of PBS, as control animals. The immunization, including the mock-immunization, was repeated once three weeks later. Three weeks after the second vaccination, all calves were intranasally 
challenged with $3 \mathrm{ml}$ of aerosolized BVDV-2 SX08 strain virus, into each nostril using a Devilbiss Atomizer (Devilbiss, Somerset, PA, USA). Each animal received approximately $10^{6.5}$ TCID $_{50}$ of the challenge virus.

Serum samples were collected from the calves immediately before the first vaccination and at the time of challenge, then were stored frozen at $-20^{\circ} \mathrm{C}$ until tested. Before the challenge, for all the animals in both groups the rectal temperatures were normal and no animal showed any clinical signs of any disease. All animals were clinically scored (Table 1) daily beginning 2 days before the challenge until 2 weeks after the challenge by two veterinarians who were blinded to the test. The parameters evaluated included alteration of the general state, rectal temperature, depression, appetite, gastrointestinal, and respiratory symptoms. Rectal temperature was measured at the same time each morning.

Table 1. Clinical Scoring System (Schnackel et al., 2007)

\begin{tabular}{|c|c|c|}
\hline Category & Score & Description \\
\hline \multirow{4}{*}{ Depression } & 0 & Normal/alert \\
\hline & 1 & Slightly depressed/subdued, but easily roused \\
\hline & 2 & Moderately depressed/some difficulty in rousing \\
\hline & 3 & Severely depressed/somnolent/cannot be roused \\
\hline \multirow{4}{*}{ Appetite } & 0 & Normal appetite/at the bunk when feed present \\
\hline & 1 & Hangs back from feed bunk/picks at hay \\
\hline & 2 & Occasionally approaches feed bunk \\
\hline & 3 & Not eating/no interest in feed \\
\hline \multirow{4}{*}{ Respiratory } & 0 & Normal respiratory rate and effort/quiet respirations \\
\hline & 1 & $\begin{array}{l}\text { Mild increase in respiratory rate and effort/occasional } \\
\text { coughing/increased nasal discharge }\end{array}$ \\
\hline & 2 & $\begin{array}{l}\text { Moderately dyspneic/increased respiratory rate and } \\
\text { effort/coughing/profuse nasal discharge }\end{array}$ \\
\hline & 3 & $\begin{array}{l}\text { Severely dyspneic/forced inspiration and expiration/profuse nasal } \\
\text { discharge }\end{array}$ \\
\hline \multirow{4}{*}{ Gastrointestinal } & 0 & Normal formed feces/if nervous - increased fluidity \\
\hline & 1 & Increased fluidity not related to nervous behavior \\
\hline & 2 & Watery, mucoid diarrhea/profuse diarrhea/straining to defecate \\
\hline & 3 & Blood, mucus, and sloughed tissue in feces/straining to defecate \\
\hline
\end{tabular}

The neutralization antibody titers to BVDV were measured using a standard microplate VN procedure with BVDV-1 NM01 strain or BVDV2 SX08 strain as the neutralizing viruses and MDBK cells as the cell line in the assay. Briefly, $56^{\circ} \mathrm{C}$-heat inactivated serum samples were twofold serially diluted in 96-well plates. Approximately $200 \mathrm{TCID}_{50}$ of the VN challenge virus was added to each diluted serum sample and incubated at $37^{\circ} \mathrm{C}$ for $1 \mathrm{~h}$. The serum-virus mixture was then inoculated onto MDBK cells. At 4-5 days post the incubation, the plates were evaluated for CPE or immunofluorescence assay. The neutralizing antibody titer for each sample was calculated using the Spearman-Kaber method (Wang et al., 2014).

Whole-blood samples were collected in tubes containing EDTA as the anticoagulant daily beginning 2 days before the challenge until 2 weeks after the challenge for leukocyte counts, which were determined using an automated cell counter (Exigo eos hematology system). Viruses were isolated from leukocytes on MDBK cells monolayers in 24-well tissue culture plates for two passages and finally were placed in 96-well tissue culture plates for an indirect immunofluorescence assay (Xue et al., 2011; Corapi et al., 1990).

The cross protection of the inactivated vaccine candidate was evaluated based on primary clinical signs, including rectal temperature, Leukopenia counts and virus isolation using Fisher Exact test of SPSS Version 20 (IBM, China). The significance of the variability among the groups was determined by one-way analysis of variance using GraphPad Prism (version 4.0, 
GraphPad Software, Inc. USA) software. Statistical significance was set at $\mathrm{P}<0.05$.

\section{RESULTS}

By the time of the challenge, i.e. at three weeks after the second vaccination, the sera titers of vaccinated groups against BVDV-1 had increased to 1:1024 (\#1801), 1:512(\#1803), 1:1024 (\#1804), 1:512 (\#1806), 1:512(\#1807), and against the BVDV-2 increased to $1: 128$ (\#1801), $\quad 1: 64 \quad$ (\#1803), 1:128(\#1804), 1:64 (\#1806), 1:128(\#1807). The animals of unvaccinated groups were free from detectable BVDV neutralising antibodies at the time of the challenge.
Five unvaccinated animals developed different extents of diarrhea, depression and nasal discharge at 6 or 7 days post challenge infection. This was moderate in two calves (\#1802 and \#1810) and severe in the three other calves (\#1805, \#1808 and \#1809). All vaccinated animals were observed with same clinical signs as unvaccinated animals, but the extent of all calves were markedly less, with lower clinical scores (Table 2). The mean clinical scores of vaccinated calves were lower than unvaccinated calves, and the vaccinated group scores were significantly $(\mathrm{P}<0.05)$ lower at $8-14$ days postchallenge than the control group (Figure 1).

Table 2. Clinical score after challenge

\begin{tabular}{|c|c|c|c|c|c|c|c|c|c|c|c|c|c|c|c|c|}
\hline \multirow{2}{*}{ Group } & \multirow{2}{*}{ Animal\# } & \multicolumn{15}{|c|}{ Days post challenge (dpc) } \\
\hline & & 0 & 1 & 2 & 3 & 4 & 5 & 6 & 7 & 8 & 9 & 10 & 11 & 12 & 13 & 14 \\
\hline \multirow{5}{*}{ Vaccinated } & 1801 & 0 & 0 & 0 & 0 & 0 & 2 & 2 & 3 & 1 & 1 & 3 & 3 & 3 & 1 & 2 \\
\hline & 1803 & 0 & 0 & 0 & 0 & 0 & 2 & 0 & 4 & 1 & 3 & 0 & 0 & 0 & 0 & 0 \\
\hline & 1804 & 0 & 0 & 0 & 0 & 0 & 1 & 1 & 1 & 2 & 2 & 2 & 2 & 1 & 2 & 0 \\
\hline & 1806 & 0 & 0 & 0 & 0 & 2 & 3 & 4 & 4 & 3 & 2 & 2 & 2 & 0 & 0 & 0 \\
\hline & 1807 & 0 & 0 & 0 & 0 & 0 & 0 & 0 & 1 & 3 & 3 & 2 & 1 & 1 & 0 & 1 \\
\hline \multirow{5}{*}{ Control } & 1802 & 0 & 0 & 0 & 0 & 0 & 1 & 1 & 3 & 2 & 3 & 4 & 5 & 7 & 4 & 3 \\
\hline & 1805 & 0 & 0 & 0 & 0 & 1 & 3 & 5 & 8 & 9 & 5 & 7 & 7 & 8 & 4 & 3 \\
\hline & 1808 & 0 & 0 & 0 & 1 & 3 & 6 & 7 & 8 & 8 & 6 & 6 & 4 & 4 & 3 & 2 \\
\hline & 1809 & 0 & 0 & 0 & 0 & 2 & 2 & 3 & 5 & 7 & 6 & 4 & 2 & 2 & 1 & 2 \\
\hline & 1810 & 0 & 0 & 0 & 0 & 0 & 2 & 3 & 6 & 4 & 5 & 4 & 4 & 2 & 3 & 2 \\
\hline
\end{tabular}

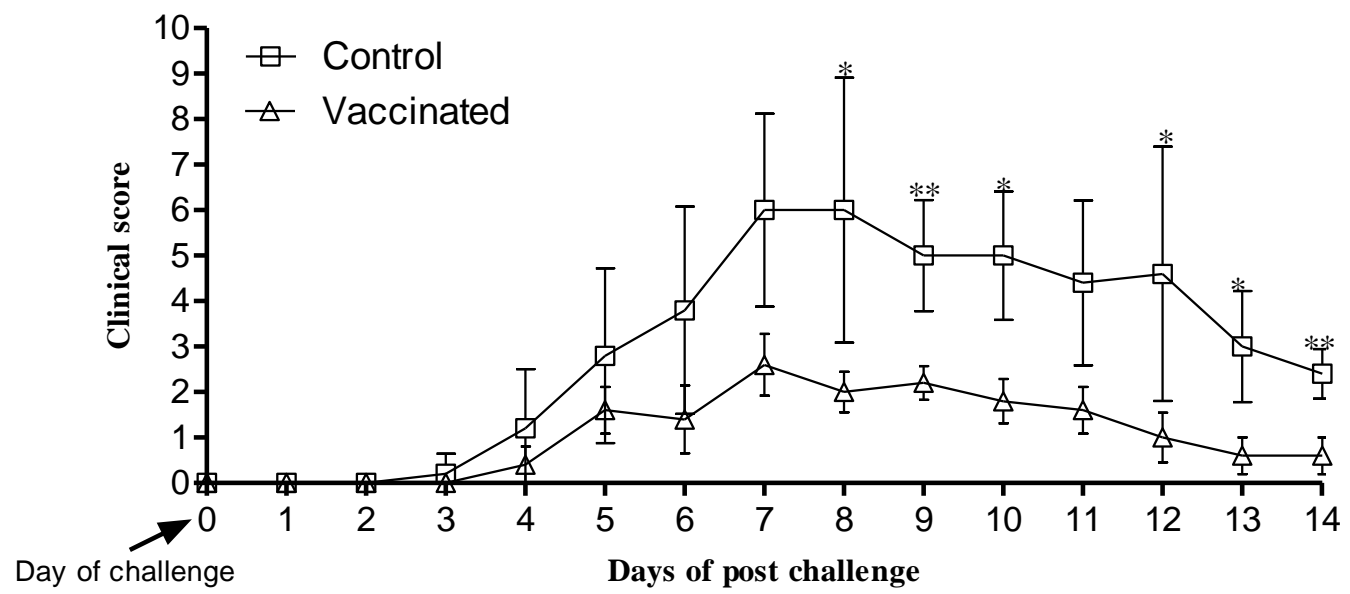

Figure 1. Mean daily clinical scores (mean \pm SD) after challenge infection of calves with BVDV type 2 strain. Five 3-4-month-old healthy Holstein calves were vaccinated twice intramuscularly, 3 weeks apart with an inactivated BVDV type 1 and IBR vaccine $(\triangle)$. Five 3-4-month-old healthy Holstein calves were not vaccinated as control $(\square)$. Twenty-one days post the second vaccination, all calves were challenged with BVDV-2 SX08 strain by spray into nostril. Statistical values are $* \mathrm{P}<0.05$ and $* * \mathrm{P}<0.01$. 
All unvaccinated animals became febrile with rectal temperatures above $40.0^{\circ} \mathrm{C}$ at 6 or 7 days post challenge infection, persisted for more than 3 days, and the highest temperature reached was $41.5^{\circ} \mathrm{C}$. On 6 days post challenge infection, the maximum rectal temperature of the vaccinated calf (\#1806) was $40.4^{\circ} \mathrm{C}$, and the other days, all rectal temperatures were within the reference range (Table 3 ). The time courses of mean rectal temperature per group are depicted in Figure 2, the mean rectal temperature of unvaccinated calves was higher than vaccinated calves. The vaccinated group had significantly $(\mathrm{P}<0.05)$ lower temperatures at 7-13 days post-challenge than the control group (Figure 2).

Table 3. Temperature after post challenge $\left({ }^{\circ} \mathrm{C}\right)$

\begin{tabular}{|c|c|c|c|c|c|c|c|c|c|c|c|c|c|c|c|c|}
\hline \multirow{2}{*}{ Group } & \multirow{2}{*}{ Animal\# } & \multicolumn{15}{|c|}{ Days post challenge (dpc) } \\
\hline & & 0 & 1 & 2 & 3 & 4 & 5 & 6 & 7 & 8 & 9 & 10 & 11 & 12 & 13 & 14 \\
\hline \multirow{3}{*}{7} & 1803 & 39.0 & 38.6 & 38.7 & 38.9 & 39.9 & 40.3 & 39.9 & 39.6 & 39.3 & 38.9 & 38.7 & 38.7 & 38.7 & 39.1 & 38.8 \\
\hline & 1806 & 39.0 & 39.2 & 39.3 & 38.9 & 38.9 & 39.7 & $\underline{40.4}$ & 39.8 & 39.8 & 39.5 & 38.6 & 38.7 & 39.0 & 38.6 & 39.0 \\
\hline & 1807 & 38.7 & 38.9 & 39.5 & 39.4 & 39.9 & 39.3 & $\overline{39.4}$ & 39.3 & 39.6 & 39.2 & 39.1 & 38.6 & 38.5 & 38.8 & 38.5 \\
\hline \multirow{3}{*}{ Control } & 1802 & 38.8 & 38.8 & 38.9 & 38.7 & 38.7 & 39.2 & 39.4 & $\underline{40.4}$ & $\underline{41.0}$ & $\underline{40.5}$ & $\underline{40.3}$ & 39.8 & 39.5 & 39.2 & 39.3 \\
\hline & 1809 & 38.9 & 38.8 & 38.6 & 39.0 & 39.0 & 39.4 & $\overline{40.8}$ & $\overline{40.7}$ & $\overline{40.6}$ & $\overline{39.7}$ & $\overline{39.5}$ & 39.2 & 39.5 & 39.1 & 38.8 \\
\hline & 1810 & 39.0 & 38.8 & 38.5 & 38.8 & 39.2 & 39.6 & 40.5 & $\overline{40.9}$ & $\overline{40.2}$ & 40.5 & 39.9 & 39.4 & 38.6 & 39.1 & 38.9 \\
\hline
\end{tabular}

Notes: ( _ ) represents rectal temperatures above $40.0^{\circ} \mathrm{C}$.

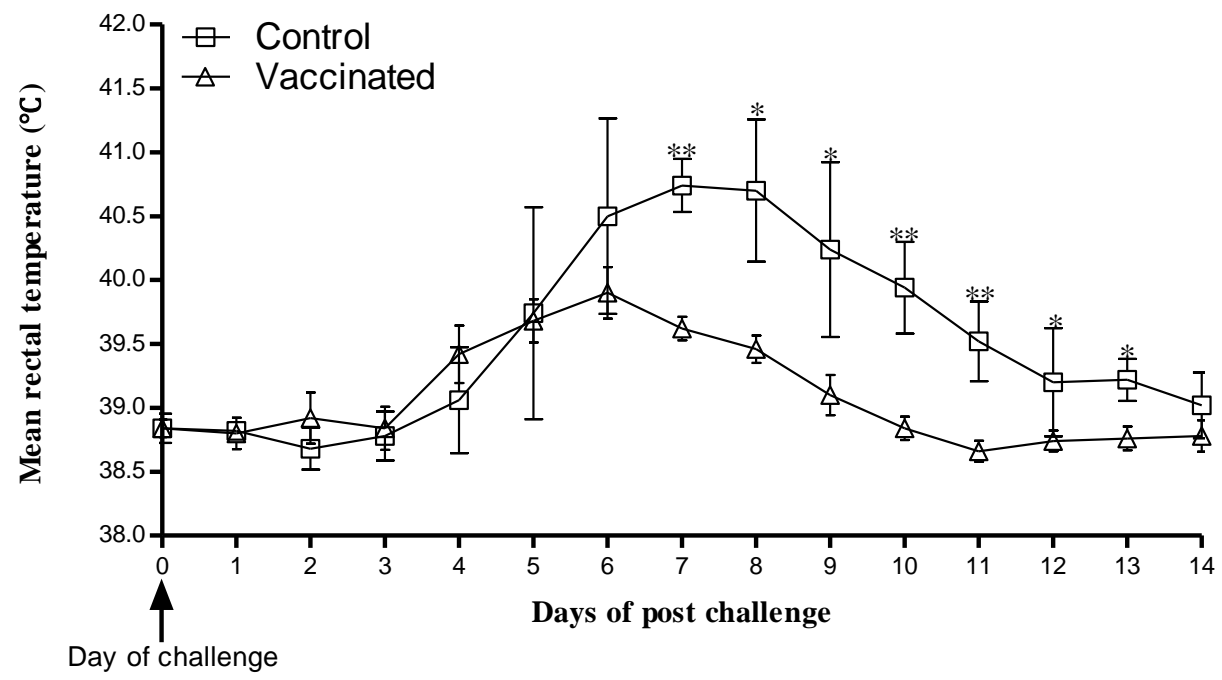

Figure 2. Mean daily rectal temperatures (mean \pm SD) after challenge infection of calves with BVDV type 2 strain. Five 3-4-month-old healthy Holstein calves were vaccinated twice intramuscularly, 3 weeks apart with an inactivated BVDV type 1 and IBR vaccine $(\triangle)$. Five 3-4-month-old healthy Holstein calves were not vaccinated as control $(\square)$. Twenty-one days post the second vaccination, all calves were challenged with BVDV-2 SX08 strain by spray into nostril. Statistical values are $* \mathrm{P}<0.05$ and $* * \mathrm{P}<$ 0.01 .

In the unvaccinated calves, there was a dramatic drop in the leukocyte counts at 5 days postchallenge, the percentage of decrease of leukocyte counts was more than $40 \%$, and persisted for more than 5 to 12 days. Leukocyte counts of the vaccinated calves dropped at 5 to 8 days post-challenge, decreased less than $35 \%$, and persisted for 3 to 5 days. The extent of leukocyte counts decrease of the unvaccinated and vaccinated calves are shown in Table 4 and Table 5. Leukopenia in the vaccinated group were significantly lower $(\mathrm{P}<0.05)$ than in the control group at 6 to 13 days (except 11) postchallenge (Figure 3). 
Table 4. Leukocyte counts post challenge $\left(\times 10^{9} / \mathrm{L}\right)$

\begin{tabular}{|c|c|c|c|c|c|c|c|c|c|c|c|c|c|c|c|c|}
\hline \multirow{2}{*}{ Group } & \multirow{2}{*}{ Animal\# } & \multicolumn{15}{|c|}{ Days post challenge (dpc) } \\
\hline & & 0 & 1 & 2 & 3 & 4 & 5 & 6 & 7 & 8 & 9 & 10 & 11 & 12 & 13 & 14 \\
\hline \multirow{3}{*}{ Vaccinated } & 1803 & 9.6 & 8.8 & 8.3 & 7.5 & 6.6 & 6.4 & 7.3 & 6.4 & 6.9 & 7.2 & 7.8 & 7.3 & 8.2 & 8.9 & 8.1 \\
\hline & 1806 & 9.3 & 9.1 & 8.7 & 8.2 & 6.8 & 6.1 & 6.3 & 6.2 & 6 & 6.5 & 8.2 & 8.6 & 8.6 & 8.3 & 8.5 \\
\hline & 1807 & 8.8 & 8.4 & 7.9 & 8.1 & 7.3 & 6.5 & 5.7 & 5.9 & 6.5 & 7.2 & 8 & 7.9 & 8.3 & 8.4 & 7.9 \\
\hline \multirow{4}{*}{ Control } & 1802 & 9.1 & 9.5 & 8.8 & 7.3 & 5.7 & 4.9 & 5.3 & 4.6 & 4.6 & 4.8 & 4.9 & 5.6 & 5.5 & 6.2 & 6.2 \\
\hline & 1808 & 10.2 & 9.4 & 8.4 & 7.2 & 6.6 & 5.4 & 5.5 & 5.3 & 5.7 & 5.7 & 6.3 & 5.8 & 5.8 & 6.7 & 7.3 \\
\hline & 1809 & 8.7 & 8.4 & 7.2 & 6.2 & 5.9 & 5 & 4.3 & 4.3 & 5.1 & 5.4 & 6.2 & 6.7 & 6.7 & 7.4 & 7.2 \\
\hline & 1810 & 8.3 & 7.8 & 7.5 & 7.3 & 6.4 & 6.2 & 4.8 & 4.3 & 4.6 & 4.6 & 5.1 & 5.8 & 6.5 & 6.4 & 7.5 \\
\hline
\end{tabular}

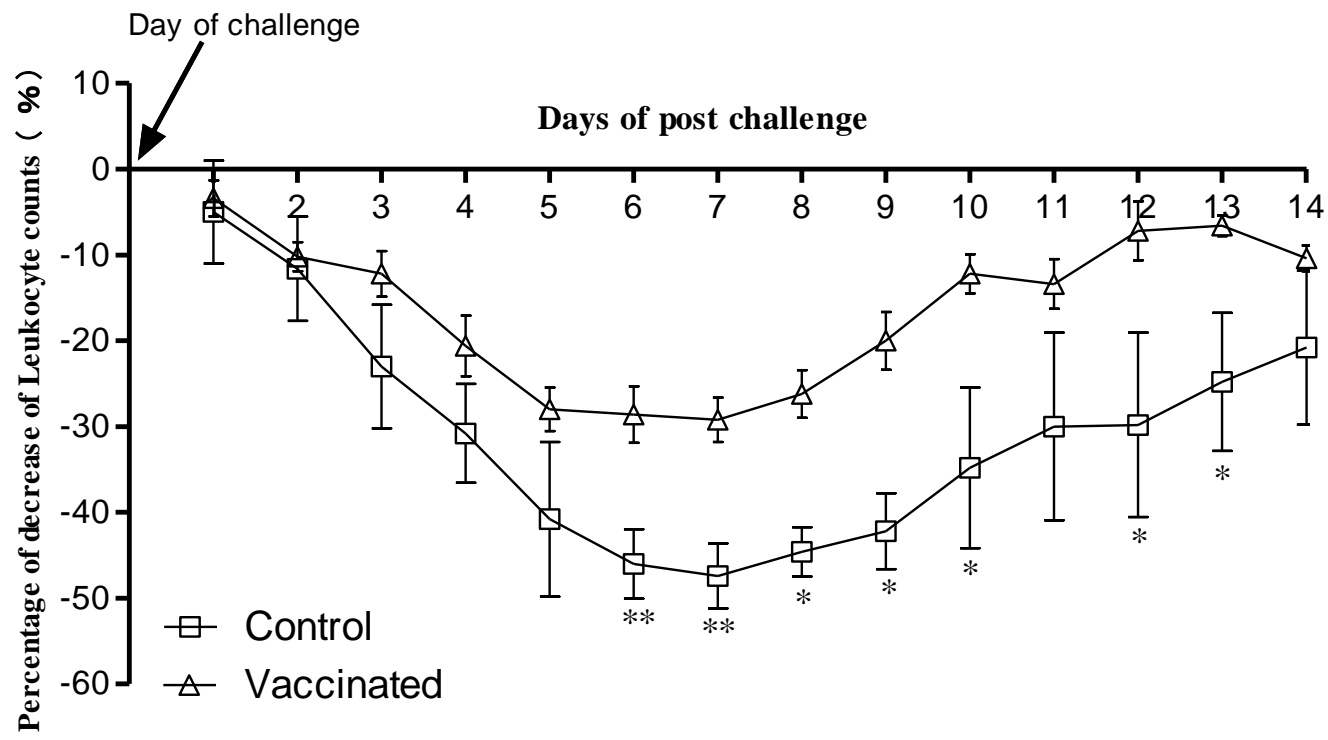

Figure 3. Mean percentage of decrease of Leukocyte counts (mean \pm SD) after challenge infection of calves with BVDV type 2 strain. Five 3-4-month-old healthy Holstein calves were vaccinated twice intramuscularly, 3 weeks apart with an inactivated BVDV type 1 and IBR vaccine $(\triangle)$. Five 3-4-monthold healthy Holstein calves were not vaccinated as control $(\square)$. Twenty-one days post the second vaccination, all calves were challenged with BVDV-2 SX08 strain by spray into nostril. Statistical values are $* \mathrm{P}<0.05$ and $* * \mathrm{P}<0.01$.

Table 5. Percentage of decrease in Leukocyte counts post challenge ( \% )

\begin{tabular}{|c|c|c|c|c|c|c|c|c|c|c|c|c|c|c|c|}
\hline \multirow{2}{*}{ Group } & \multirow{2}{*}{ Animal\# } & \multicolumn{14}{|c|}{ Days post challenge (dpc) } \\
\hline & & 1 & 2 & 3 & 4 & 5 & 6 & 7 & 8 & 9 & 10 & 11 & 12 & 13 & 14 \\
\hline \multirow{4}{*}{ Vaccinated } & 1801 & -6 & -14 & -12 & -14 & -20 & -18 & -20 & -18 & -11 & -6 & -10 & 5 & -6 & -10 \\
\hline & 1803 & -8 & -14 & -22 & -31 & -33 & -24 & -33 & -28 & -25 & -19 & -24 & -15 & -7 & -16 \\
\hline & 1806 & -2 & -6 & -12 & -27 & -34 & -32 & -33 & -35 & -30 & -12 & -8 & -8 & -11 & -9 \\
\hline & 1807 & -5 & -10 & -8 & -17 & -26 & -35 & -33 & -26 & -18 & -9 & -10 & -6 & -5 & -10 \\
\hline \multirow{3}{*}{ Control } & 1802 & 4 & -3 & -20 & -37 & $\underline{-46}$ & -42 & -49 & -49 & -47 & -46 & -38 & -40 & -32 & -32 \\
\hline & 1809 & -3 & -17 & -29 & -32 & -43 & -51 & -51 & -41 & -38 & -29 & -23 & -23 & -15 & -17 \\
\hline & 1810 & -6 & -10 & -12 & -23 & -25 & -42 & -48 & -45 & $\underline{-45}$ & -39 & -30 & -22 & -23 & -10 \\
\hline
\end{tabular}

Notes: ( _ ) represents the percentage of decrease of leukocyte counts was more than $40 \%$. 
All unvaccinated and vaccinated calves were BVDV-negative for virus isolation at the time of challenge. Except for one vaccinated calf, which was tested positive only at 4 to 6 days post challenge, the other vaccinated and unvaccinated calves were tested positive at 2 or 3 to 11 or 13 days post challenge, and persisted for more than 7 days (Table 6).

Table 6. Virus isolation after challenge

\begin{tabular}{|c|c|c|c|c|c|c|c|c|c|c|c|c|c|c|c|c|}
\hline \multirow{2}{*}{ Group } & \multirow{2}{*}{ Animal\# } & \multicolumn{15}{|c|}{ Days post challenge (dpc) } \\
\hline & & 0 & 1 & 2 & 3 & 4 & 5 & 6 & 7 & 8 & 9 & 10 & 11 & 12 & 13 & 14 \\
\hline \multirow{3}{*}{ Vaccinated } & 1803 & - & - & - & - & + & + & + & + & - & - & - & - & - & - & - \\
\hline & 1806 & - & - & - & - & + & + & + & + & - & - & - & - & - & - & - \\
\hline & 1807 & - & - & - & - & - & + & + & + & - & - & - & - & - & - & - \\
\hline \multirow{4}{*}{ Control } & 1802 & - & - & - & + & + & + & + & + & + & + & + & + & + & + & - \\
\hline & 1808 & - & - & - & - & + & + & + & + & + & + & + & + & + & + & + \\
\hline & 1809 & - & - & + & + & + & + & + & + & + & + & + & - & - & - & - \\
\hline & 1810 & - & - & - & - & + & + & + & + & + & + & + & - & - & - & - \\
\hline
\end{tabular}

Notes: “-”: BVDV-negative, “+”: BVDV-positive

\section{DISCUSSION}

BVDV-2 infection causes a syndrome in young calves that is characterized by leukopenia, pyrexia, diarrhea and asthma (Wang et al., 2016). According to the clinical symptoms after infection, BVDV-2 can be divided into high virulent, moderate virulent and low virulent. Cattle infected with a low virulent virus showed mild clinical signs, accompanied by light fever (rectal temperatures between 39.2 and $40.0^{\circ} \mathrm{C}$ ) less than three days and a decrease of leukocyte counts less than $40 \%$. High virulent virusinfected cattle showed a clinical presentation with a high fever above $40.0^{\circ} \mathrm{C}$, even to $41.7^{\circ} \mathrm{C}$, and persisted for 3 or more days, the WBC and platelets both dropped below 40\% (Odeón et al.,
1999; Archambault et al., 2000; Kelling et al., 2002).

One BVDV-2 virus, which infected cattle showed a clinical sign with rectal temperature higher than the base temperature $1^{\circ} \mathrm{C}$ at least 1 day, and leukocyte counts decreased by over $40 \%$, can be classified as a moderate virulent virus (Wang et al., 2016). In this study, all unvaccinated cattle, infected with BVDV-2 SX08 strain, showed serious clinical symptoms, such as body high fever above $40.0{ }^{\circ} \mathrm{C}$, persisted for 3 days, and the highest reached $41.5^{\circ} \mathrm{C}$, a decrease of leukocyte counts below $40 \%$, persisted for 4 or more days, the max up to $51 \%$. Thus, the BVDV-2 SX08 strain is a high virulent virus strain (Table 7).

Table 7. Leukopenia, viraemia and temperature of vaccinated and control animal groups

\begin{tabular}{|c|c|c|c|c|c|c|}
\hline Group & Animal\# & $\begin{array}{c}\text { Total days with } \\
\text { temperature }>40.0{ }^{\circ} \mathrm{C}^{\text {a }}\end{array}$ & $\begin{array}{c}\text { Highest } \\
\text { temperature }^{b}\end{array}$ & $\begin{array}{l}\text { Highest scores } \\
\text { of Clinical }^{c}\end{array}$ & $\underset{\mathrm{d}}{\operatorname{Leukopenia}}(\%)$ & $\begin{array}{c}\text { Virus } \\
\text { isolation }^{\mathrm{e}}\end{array}$ \\
\hline \multirow{4}{*}{ Vaccinated } & 1801 & 0 & 39.9 & 3 & 0 & 3 \\
\hline & 1803 & 1 & 40.2 & 4 & 0 & 4 \\
\hline & 1806 & 2 & 40.4 & 4 & 0 & 4 \\
\hline & 1807 & 0 & 39.9 & 3 & 0 & 3 \\
\hline \multirow[t]{3}{*}{ Control } & 1808 & 5 & 41.5 & 8 & 7 & 11 \\
\hline & 1809 & 3 & 40.8 & 7 & 4 & 9 \\
\hline & 1810 & 4 & 40.9 & 6 & 4 & 7 \\
\hline
\end{tabular}

Notes: a: Total days with temperature $>40.0^{\circ} \mathrm{C}$ during 1 to 14 days post challenge (dpc).

b: The highest rectal temperature during 1 to $14 \mathrm{dpc}$.

c: The highest scores of Clinical during 1 to $14 \mathrm{dpc}$.

$\mathrm{d}$ : Total days with percentage of decrease of Leukocyte counts $>40.0 \%$ during 1 to $14 \mathrm{dpc}$, compared to an average of two pre-challenge values.

e: Total days with virus isolation positive. 
This challenge model was used to determine the efficacy of a combo inactivated vaccine for BVDV-1 and IBRV in protection against a BVDV-2 strain. the previous studies have proved that BVDV-1 vaccine can decrease the BVDV-2. The efficacy of live BVDV-1 vaccines against type 2 challenge has been demonstrated by Dean and colleagues (Dean and Leyh, 1999), B.Makoschey (Makoschey et al., 2001) suggest that the cross protection of the BVDV-1 inactivated vaccines against BVDV-2 is satisfactory, but the results of Potgieter and colleagues (Potgieter, 1995) questioned the efficacy of killed virus vaccines at least in heterologous protection.

In this study, all unvaccinated calves exhibited serious clinical symptoms post challenge, such as a decrease of leukocyte counts below $40 \%$ persisted for 4 or more days, pyrexia above $40.0^{\circ} \mathrm{C}$ persisted for 3 or more days, viraemia persisted for 7 or more days. All vaccinated calves presented only mild clinical signs, such as a decrease of leukocyte counts below 35\%, viraemia persisted less than 5 or less days, and three of five calves' rectal temperature higher than $40.0^{\circ} \mathrm{C}$ just persisted for 1 day. Bolin and Beer suggest that the level of neutralising antibodies is critical for protection, the level of neutralizing antibodies titer is $1: 128$ giving partially protected, a titer at 1:256 is sufficient for preventing clinical signs and viremia virus shedding (Bolin and Ridpath, 995; Beer et al., 2000). In the test, the BVDV-2 neutralization antibody titer of all vaccinated calfs were up to $1: 64$, which may be the main reason why the clinical symptoms and viremia were significantly reduced after challenged with BVDV-2 SX08 strain.

\section{CONCLUSION}

BVDV-2 SX08 strain is a high virulent strain, which can cause severe clinical symptoms in infected cattle. In this experiment, the combo inactivated vaccine for BVDV-1 and IBRV affords cross protection against clinical effects of a challenge-infection with BVDV-2 SX08 strain.

\section{CONFLIT OF INTEREST STATEMENT}

The authors have agreed that there is no conflict of interest between them.

\section{ACKNOWLEDGEMENTS}

The authors thank all of the technicians who were involved in the animal care and sample collection. This study was supported by National Key R\&D Program (2017YFD0500904).

\section{REFERENCES}

ARCHAMBAULT, D.; BÉLIVEAU, C.; COUTURE, Y.; CARMAN, S. Clinical response and immunomodulation following experimental challenge of calves with type 2 noncytopathogenic bovine viral diarrhea virus. Vet. Res., v.31, p.215-227, 2000.

BAKER, J.C. The clinical manifestations of bovine viral diarrhea infections. Vet. Clin. N. Am. Food Anim. Pract., v.11, p.425-445, 1995.

BEER, M.; HEHNEN, H.R.; WOLFMEYER, A.; POLL, G. et al. A new inactivated bvdv genotype $\mathrm{i}$ and ii vaccine. an immunisation and challenge study with bvdv genotype i. Vet. Microbiol., v.77, p.195-208, 2000.

BOLIN, S.R.; RIDPATH, J.F. Assessment of protection from systemic infection or disease afforded by low to intermediate titers of passively acquired neutralizing antibody against bovine viral diarrhea virus in calves. Am. J. Vet. Res., v.56, p.755-759, 1995.

CORAPI, W.V.; DONIS, R.O.; DUBOVI, E.J. Characterization of a panel of monoclonal antibodies and their use in the study of the antigenic diversity of bovine viral diarrhea virus. Am. J. Vet. Res., v.51, p.1388-1394, 1990.

DEAN, H.J.; LEYH, R. Cross-protective efficacy of a bovine viral diarrhea virus (bvdv) type 1 vaccine against BVDV-2 challenge. Vaccine, v.17, p.1117, 1999.

FAIRBANKS, K.; SCHNACKEL, J.; CHASE, C.C. Evaluation of a modified live virus type-1a bovine viral diarrhea virus vaccine (singer strain) against a type-2 (strain 890) challenge. Vet. Therap. Res. Appl. Vet. Med., v.4, p.24, 2003.

HAMERS, C.; COUVREUR, B.; DEHAN, P.; LETELLIER, C.; FISCHER, L. et al. Assessment of the clinical and virological protection provided by a commercial inactivated bovine viral diarrhoea virus genotype 1 vaccine against a bvdv genotype 2 challenge. Vet. Rec., 1.53, p.236-240, 2003. 
KELLING，C.L.; STEFFEN，D.J.; TOPLIFF, C.L.; ESKRIDGE, K.M. et al. Comparative virulence of isolates of bovine viral diarrhea virus type ii in experimentally inoculated six- to nine-month-old calves. Am. J. Vet. Res., v.63, p.1379, 2002.

MAKOSCHEY, B.; JANSSEN, M.G.; VRIJENHOEK, M.P.; KORSTEN, J.H.; MAREL, P. An inactivated bovine virus diarrhoea virus (bvdv) type 1 vaccine affords clinical protection against BVDV-2. Vaccine, v.19, p.3261-3268, 2001.

MOENNIQ, V.; BECHER, P. Control of bovine viral diarrhea. Pathoqens, v.7, p.29, 2018.

ODEÓN, A.C.; KELLING, C.L.; MARSHALL, D.J.; ESTELA, E.S. et al. Experimental infection of calves with bovine viral diarrhea virus genotype ii (ny-93). J. Vet. Diag. Invest. Off. Publ. Am. Assoc. Vet. Lab. Diag., v.11, p.221, 1999.

POTGIETER, L.N. Immunology of bovine viral diarrhea virus. Vet. Clin. N. Am. Food Anim. Pract., v.11, p.501-520, 1995.

RIDPATH, J.F.; BOLIN, S.R.; DUBOVI, E.J. Segregation of bovine viral diarrhea into genotypes. Virol, v.205, p.66-74, 1994.

SCHNACKEL, J.A.; VAN CAMPEN, H.; VAN OLPHEN, A. Modified-live bovine viral diarrhea virus (BVDV) type 1a vaccine provides protection against fetal infection after challenge with either type $1 \mathrm{~b}$ or type $2 \mathrm{BVDV}$. Bovine Pract., v.41, p.1-9, 2007.
SHIMAZAKI, T.; NAKAMURA, S.; TAGUCHI, K.; INOUE, Y. Efficacy of bovine viral diarrhea vaccine used in japan against bovine viral diarrhea virus type 2 strain 890. J. Vet. Med. Sci., v.65, p.263, 2003.

WANG, W.; SHI, X.; WU, Y.; LI, X. et al. Immunogenicity of an inactivated chinese bovine viral diarrhea virus 1a (bvdv 1a) vaccine cross protects from bvdv $1 \mathrm{~b}$ infection in young calves. Vet. Immunol. Immunopathol., v.160, p.288-292, 2014.

WANG, W.; SHI, X.; XIA, M.; WU, H. Pathogenicity of a Non-cytopathic Bovine Viral Diarrhea Virus 2b strain isolated from cattle in China. Austin Virol. Retro Virol., v.3, p.1024, 2016.

XUE, F.; ZHU, Y.M.; LI, J.; ZHU, L.C.; REN, X.G. et al. Genotyping of bovine viral diarrhea viruses from cattle in china between 2005 and 2008. Vet. Microbiol., v.143, p.379-383, 2010.

XUE, W.; MATTICK, D.; SMITH, L. Protection from persistent infection with a bovine viral diarrhea virus (bvdv) type $1 \mathrm{~b}$ strain by a modified-live vaccine containing bvdv types $1 \mathrm{a}$ and 2, infectious bovine rhinotracheitis virus, parainfluenza 3 virus and bovine respiratory syncytial virus. Vaccine, v.29, p.4657-4662, 2011.

XUE, W.; MATTICK, D.; SMITH, L.; MAXWELL, J. Fetal protection against bovine viral diarrhea virus types 1 and 2 after the use of a modified-live virus vaccine. Can. J. Vet. Res, Rev. Can. Recherche Vet., v.73, p.292-297, 2009. 